\title{
VIIRS-Derived Water Turbidity in the Great Lakes
}

\author{
Seunghyun Son ${ }^{1,2, *}$ and Menghua Wang ${ }^{1}$ (D) \\ 1 National Oceanic and Atmospheric Administration, National Environmental Satellite, Data, and Information \\ Service, Center for Satellite Applications and Research, E/RA3, 5830 University Research Ct., College Park, \\ MD 20740, USA; Menghua.Wang@noaa.gov \\ 2 Cooperative Institute for Research in the Atmosphere at Colorado State University, Fort Collins, \\ CO 80523, USA \\ * Correspondence: Seunghyun.Son@noaa.gov; Tel.: +1-301-683-3324; Fax: +1-301-683-3301
}

Received: 29 April 2019; Accepted: 14 June 2019; Published: 18 June 2019

\begin{abstract}
Satellite ocean color products from the Visible Infrared Imaging Radiometer Suite (VIIRS) onboard the Suomi National Polar-orbiting Partnership (SNPP) since 2012 and in situ water turbidity measurements from the U.S. Environmental Protection Agency's Great Lakes Environmental Database System are used to develop a water turbidity algorithm for satellite ocean color applications in the Great Lakes for water quality monitoring and assessments. Results show that the proposed regional algorithm can provide reasonably accurate estimations of water turbidity from satellite observations in the Great Lakes. Therefore, VIIRS-derived water turbidity data are used to investigate spatial and temporal variations in water turbidity for the entirety of the Great Lakes. Water turbidity values are overall the highest in Lake Erie, moderate in Lake Ontario, and relatively low in lakes Superior, Michigan, and Huron. Significantly high values in water turbidity appear in the nearshore regions, particularly in Thunder Bay (Lake Superior), Green Bay (Lake Michigan), and Saginaw Bay (Lake Huron). Seasonal patterns of water turbidity are generally similar in lakes Superior, Michigan, Huron, and Ontario, showing relatively high values in the spring and autumn months and lows in the winter season, while the seasonal pattern in Lake Erie is apparently different from the other lakes, with the highest value in the winter season and the lowest in the summer season. A strong interannual variability in water turbidity is shown in the time series of the VIIRS-derived water turbidity data for most of the lakes.
\end{abstract}

Keywords: Great Lakes; water turbidity; VIIRS; ocean color data; remote sensing

\section{Introduction}

The world's largest lakes, the Great Lakes, contain one-fifth of world's surface freshwaters, covering about $245,000 \mathrm{~km}^{2}$ (Figure 1). The Great Lakes provide drinking water, food, and transportation to nearly one-eighth of the population of the United States and one-third of the population of Canada, and therefore, they have significant contributions to the economic and recreational activities of North America. The Great Lakes are influenced by riverine inputs-including suspended sediments and organic materials from nearby cities and industries-and shoreline erosion, which can alter water quality and enhance the eutrophication [1-4]. With the successful launches of satellite ocean color sensors, such as the Coastal Zone Color Scanner (CZCS) [5,6], the Sea-viewing Wide Field-of-view Sensor (SeaWiFS) [7], the Moderate Resolution Imaging Spectroradiometer (MODIS) [8] on the Terra and Aqua, the Visible Infrared Imaging Radiometer Suite (VIIRS) [9] on the Suomi National Polar-orbiting Partnership (SNPP) and NOAA-20, the Ocean and Land Colour Instrument (OLCI) on the Sentinel-3A and Sentinel-3B, and the Second-Generation Global Imager (SGLI) on the Global Change Observation Mission-Climate (GCOM-C), satellite remote sensing observations have been playing important roles in the monitoring and investigating of water quality properties and marine ecological features in 
a broad area of the Great Lakes with both high spatial and temporal scales. In particular, satellite algorithms have been developed for various applications in the Great Lakes, such as estimating water quality properties and biogeochemical parameters [10-16] and monitoring harmful algal blooms (HABs) [17-19]. An ice-detection algorithm for the Great Lakes has been developed for satellite ocean color data processing for MODIS-Aqua and VIIRS-SNPP [20]. The ice-detection method can identify ice-contaminated pixels well and provide more accurate satellite ocean color products during the winter season in the Great Lakes [20]. As impacts of climate and environmental changes on the Great Lakes ecosystem are more recognized [21-24], there are increased interests and concerns for routine water clarity or water turbidity observations. Recent studies have demonstrated that the water clarity measurements from satellite observations using the Secchi depth $[12,16,25]$ can be related to the water diffuse attenuation coefficient at the wavelength of $490 \mathrm{~nm} K_{d}(490)$ [26,27]. Those studies were mostly focused on an individual or upper lake in the Great Lakes or on the long-term decadal changes in water clarity rather than spatial and seasonal distributions in the entirety of the Great Lakes. In addition, Secchi depths are measured by visual inspection, and although the Secchi depth is a useful indicator to estimate water clarity, there may be more uncertainties in Secchi depth observations compared with other parameters from instrumental observations. Thus, there is still a need to improve the retrieval algorithm for satellite water turbidity products for the Great Lakes.

In this study, using the in situ water turbidity measurements and the VIIRS-derived ocean color products, a regional water turbidity algorithm for the Great Lakes from satellite ocean color observations is developed. The proposed turbidity method is then applied to VIIRS-SNPP data from 2012 to 2018 to generate synoptic maps and a time series of the VIIRS-measured water turbidity in the Great Lakes. We study and investigate VIIRS-derived water turbidity product data and images, and we generate a time series to characterize spatial and temporal distributions of water turbidity in the Great Lakes.

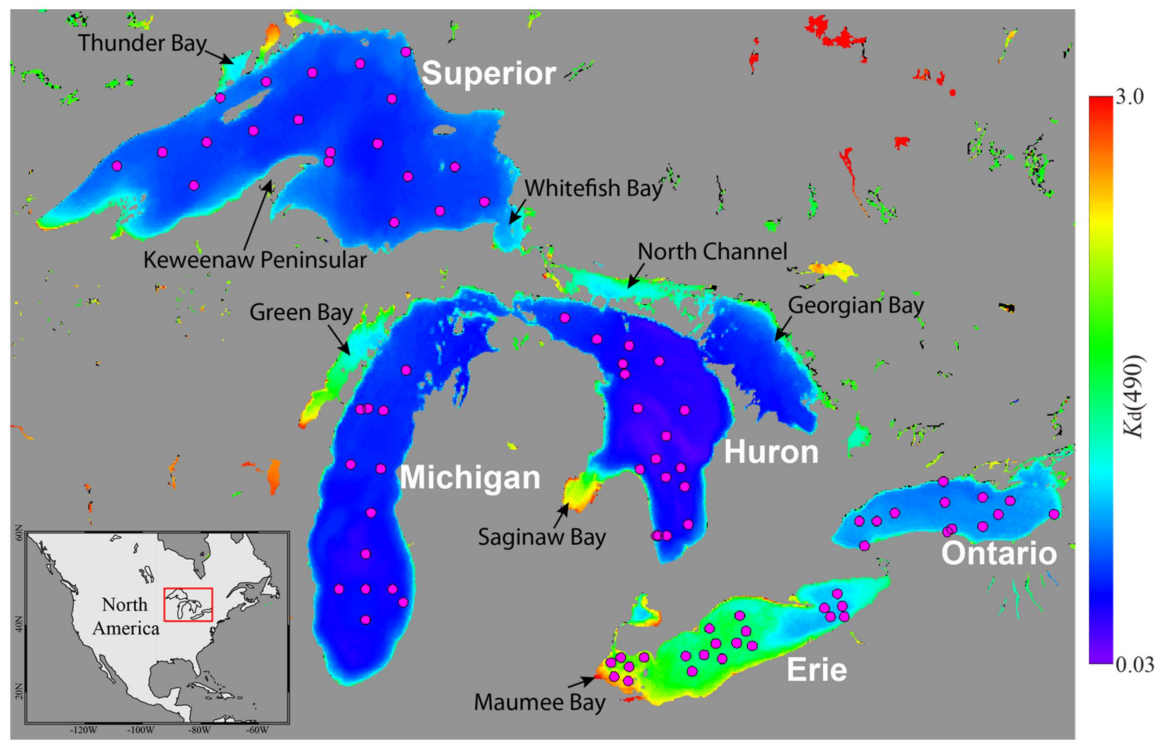

Figure 1. Map of the Great Lakes with the marks (pink circles) indicating in situ data locations for water turbidity measurements on the Visible Infrared Imaging Radiometer Suite (VIIRS)-derived climatology $K_{d}(490)$ image (2012-2018). Names of the five lakes are noted in the right side of lakes, and the map of North America is also shown in the left bottom as the location of the Great Lakes indicated in the red box.

\section{Data and Methods}

\subsection{VIIRS-SNPP Ocean Color Data}

VIIRS-SNPP ocean color Environmental Data Records (EDR or Level-2 data) [28,29] are routinely produced from Sensor Data Records (SDR or Level-1B products) after sensor on-orbit calibrations [30,31] 
using the Multi-Sensor Level-1 to Level-2 (MSL12) ocean color data processing system, which is the official VIIRS ocean color data processing system. MSL12 was originally developed for providing consistent ocean color products from multiple satellite sensors [32-34]. VIIRS ocean color data from 2012 to 2018 over the entirety of the Great Lakes were generated using the MSL12 ocean color data processing system with the combined near-infrared (NIR) and shortwave infrared (SWIR) atmospheric correction algorithm [35-41]. VIIRS Level-2 data were remapped to a standard Mercator projection at a 1-km spatial resolution after applying the refined regional ice-detection algorithm for the Great Lakes [20] to remove ice-contaminated pixels during the winter season. The remapped VIIRS data were used to generate various composite images of water turbidity products in the Great Lakes. Monthly composites of VIIRS-derived water turbidity products from 2012 to 2018 were used for climatology monthly composite images. Then, the climatology composite image was generated using the climatology monthly composite images. In addition, the time series of mean water turbidity values for the individual lake from the monthly composite images of the VIIRS-derived water turbidity data were produced for the Great Lakes. Pixels with a $5 \times 5$ box centered at a location of in situ measurements were extracted from VIIRS Level-2 data after applying the five flags to mask high uncertainty data to be compared with the in situ turbidity measurements for evaluation and validation. Specifically, these five flags are high sensor-zenith angle, high solar-zenith angle, high sun glint, stray light, and absorbing aerosols. For the satellite in situ data matchup analyses, we have followed the procedure discussed in Wang et al. [41].

\subsection{In Situ Water Turbidity Measurements}

In situ water quality parameters are periodically measured in the Great Lakes by the U.S. Environmental Protection Agency (EPA) in the spring (April or May) and summer (August or September). In situ water turbidity measurements in the Nephelometric Turbidity Unit (NTU) were downloaded for all of the lakes for the period of 1983-2017 from the EPA's Great Lake Environmental Database System (GLENDA) to develop a regional water turbidity algorithm for satellite data applications (Figure 1). The in situ water turbidity data have also been used to validate the new regional satellite water turbidity algorithm for the Great Lakes, as well as evaluate the VIIRS-derived water turbidity products.

\section{Results}

\subsection{Comparison of VIIRS-Derived $K_{d}(490)$ and In Situ-Measured Water Turbidity}

Since we do not have in situ radiometric measurements for the Great Lakes, the in situ water turbidity measurements from GLENDA were compared with the VIIRS-derived ocean color products using the NIR-SWIR atmospheric correction algorithm $[37,39]$ to derive a regional water turbidity algorithm for satellite ocean color applications. After investigating various approaches including comparisons with VIIRS-derived chlorophyll-a and combinations of normalized water-leaving radiance $n L_{w}(\lambda)$ at various wavelengths, it was found that the Great Lakes in situ water turbidity data have a strong correlation with the VIIRS-derived $K_{d}(490)$ data that are derived using the semi-analytical $K_{d}(490)$ model [27]. It should be noted that for highly turbid waters (e.g., Lake Okeechobee in Florida), $n L_{w}(\lambda)$ at the NIR bands should be used for deriving water turbidity [42,43]. The in situ turbidity measurements corresponding to the valid VIIRS-derived $K_{d}(490)$ in the period of 2012-2017 are available as 74 data points. Figure 2 provides the matchup comparison results between in situ water turbidity and the VIIRS-derived $K_{d}(490)$ data. The comparison results show that water turbidity measurements are strongly correlated to VIIRS-derived $K_{d}(490)$ in the Great Lakes (as expected), with a correlation coefficient of 0.93 . Therefore, a new regional water turbidity algorithm for the Great Lakes, covering water turbidity values of 0.1 to $23.0 \mathrm{NTU}$, can be expressed as

$$
\text { Turbidity }=10^{\left(0.523+1.294 X+0.306 X^{2}+0.205 X^{3}\right)}
$$


where $X=\log \left[K_{d}(490)\right]$. Therefore, water turbidity is effectively related to satellite-measured $n L_{w}(\lambda)$ at the blue, green, and red bands that are used for deriving $K_{d}(490)$ data [27]. For verification and evaluation, VIIRS-derived water turbidity data using Equation (1) for the Great Lakes were compared with the in situ measurements. Figure 3 a provides the matchup comparison results between VIIRS-derived and in situ-measured water turbidity data. VIIRS-derived water turbidity data are in agreement with those from the in situ measurements. The mean and median ratios of the VIIRS-derived to the in situ-measured turbidity data in the Great Lakes are 1.100 and 1.002, respectively. Comparisons of histogram results for the VIIRS-derived and in situ-measured water turbidity data are also shown in Figure $3 \mathrm{~b}$. Since most of the in situ water turbidity data were measured in the months of May and August, all daily VIIRS-derived water turbidity data from these two months in 2012-2018 were used to derive the VIIRS histogram in Figure $3 \mathrm{~b}$. The total numbers of the VIIRS-derived and in situ-measured water turbidity data that are used for the histograms are about $2.8 \times 10^{7}$ and 613 , respectively. Results in Figure 3 show that the distribution of the VIIRS-derived water turbidity is well matched with that of the in situ measurements. Both VIIRS and in situ water turbidity values range from $\sim 0.06$ to 20 NTU in the histograms (Figure $3 b$ ), and both peaks are located around 0.1-0.2 NTU. Thus, VIIRS-derived water turbidity data using the new proposed regional algorithm can be applied to study and characterize water properties in the Great Lakes.

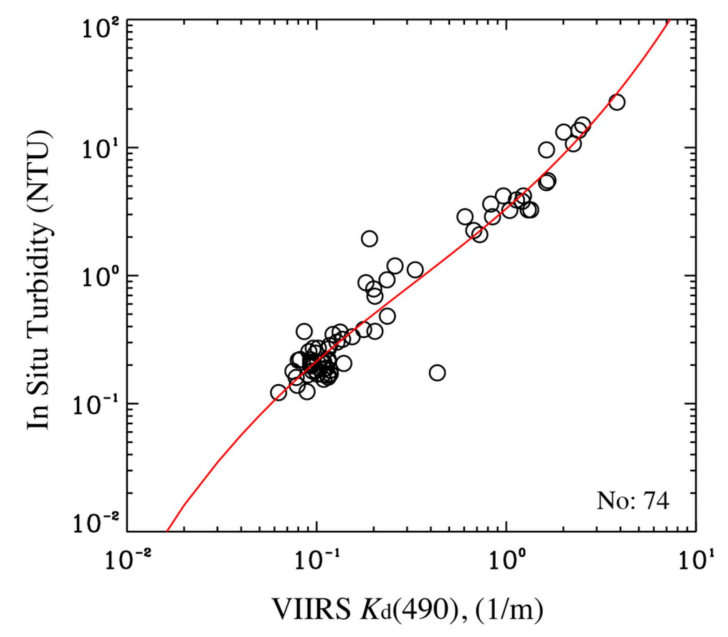

Figure 2. In situ-measured water turbidity (NTU) as a function of VIIRS-Suomi National Polar-orbiting Partnership (SNPP)-derived $K_{d}(490)$ for the Great Lakes.
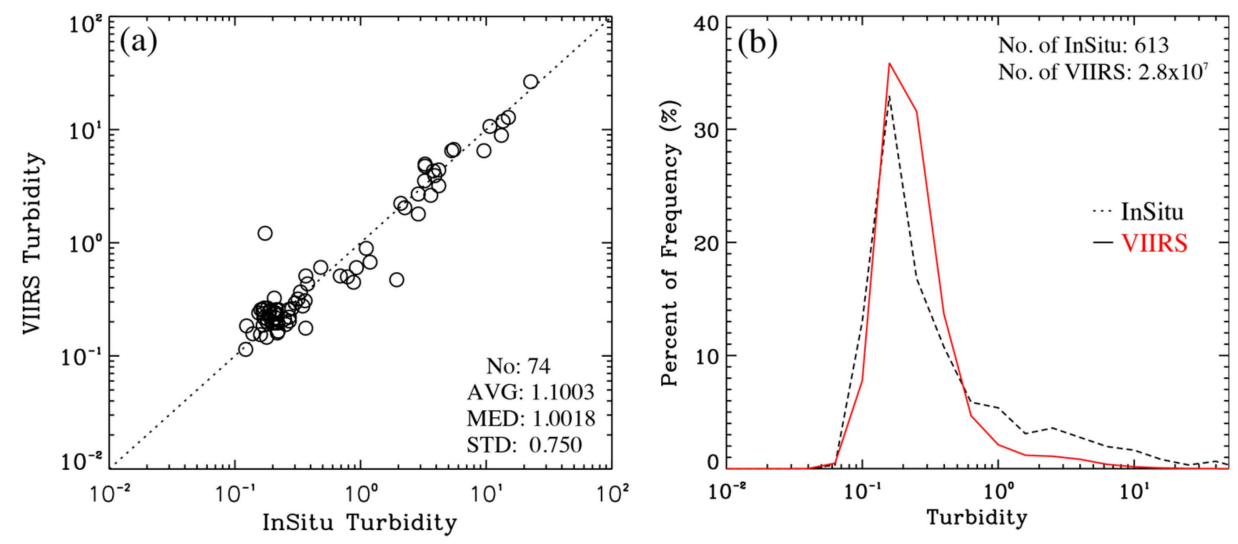

Figure 3. VIIRS-SNPP-derived water turbidity data (2012-2018) in the Great Lakes compared with the in situ turbidity measurements for (a) matchup comparison and (b) histogram results. 


\subsection{VIIRS-Derived Monthly Climatology Water Turbidity Images}

Figure 4 provides VIIRS-derived monthly climatology (2012-2018) water turbidity images in the Great Lakes using the NIR-SWIR atmospheric correction in MSL12 and a newly proposed regional turbidity algorithm (Equation (1)). Overall, the spatial pattern shows that water turbidity is generally low in Lake Michigan and Lake Huron, and it is relatively high in Lake Superior and Lake Ontario. The highest water turbidity value appears in Lake Erie during all months compared to those in the other lakes. However, seasonal and spatial variations in water turbidity vary and depend on the specific lake. In most areas of lakes Superior, Michigan, Huron, and Ontario, the water turbidity is the lowest during the winter months (December to January), and their values increase in the spring. A slight decrease in the water turbidity appears in the summer. In the autumn, the water turbidity increases again, and the highest value appears in October and November. However, seasonal patterns in the nearshore waters, e.g., Thunder Bay, Green Bay, and Saginaw Bay, are somewhat different from those in middle of the lakes, showing the highest in the winter and relatively lower in the summer. Unlike the other lakes, the water turbidity in Lake Erie is the highest during the winter months, which is possibly due to shallow bathymetry [3]. The water turbidity decreases in the spring and is the lowest in the summer. In spatial distribution, there is a big contrast between the western and eastern side of Lake Erie (higher in the western to middle area and lower in the eastern area).

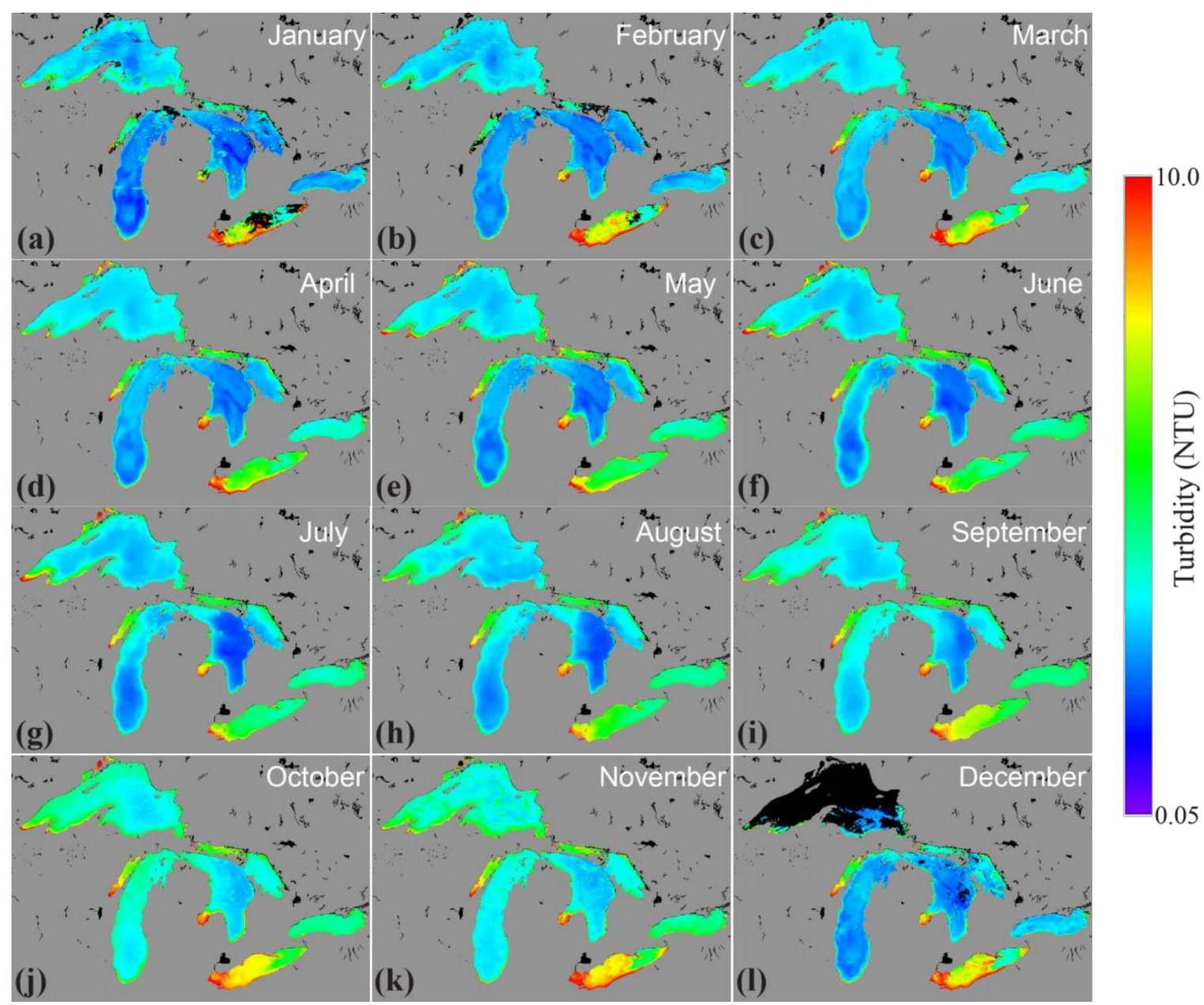

Figure 4. VIIRS-SNPP-measured monthly climatology (2012-2018) turbidity images for the Great Lakes for the months of (a)-(1) as January-December. 


\subsection{Seasonal and Interannual Variability in Water Turbidity}

Mean water turbidity values for the entire area of each individual lake in the Great Lakes were derived from monthly and climatology monthly composites of the VIIRS-derived water turbidity to study the seasonal and interannual variability. Figure 5a-e provides the seasonal distribution of the VIIRS-derived monthly water turbidity climatology (2012-2018) for lakes Superior, Michigan, Huron, Erie, and Ontario, respectively. Figure $5 \mathrm{f}$ provides the corresponding standard deviation (STD) values for these lakes from the monthly climatology water turbidity data. The average seasonal patterns of water turbidity are similar in lakes Superior, Michigan, and Huron, showing that water turbidity values are the lowest in the winter (December to February) and the highest in the month of October. The water turbidity is relatively higher in the spring and slightly decreased in the summer (July or August). The seasonal pattern in Lake Ontario is generally similar to but somewhat different from that in the three other lakes (Superior, Michigan, and Huron), with the highest turbidity in September. As described above and shown also in Figure 4, the seasonal pattern of water turbidity in Lake Erie is distinctly different from those in the other lakes. In Lake Erie, specifically, the highest water turbidity values appeared in January to February, while the lowest values were during the summer months (June to August).

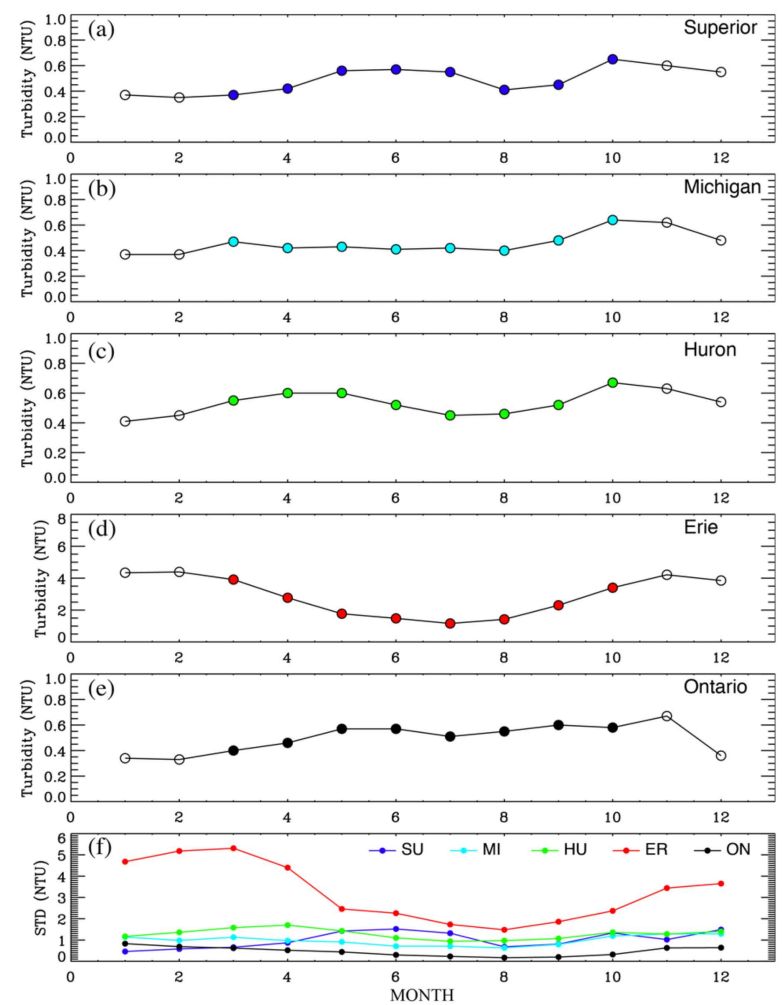

Figure 5. VIIRS-SNPP-derived mean climatology (2012-2018) monthly water turbidity in the Great Lakes for (a) Lake Superior, (b) Lake Michigan, (c) Lake Huron, (d) Lake Erie, and (e) Lake Ontario. Plot (f) shows standard deviation (STD) values from climatology monthly water turbidity data for the five corresponding lakes. Filled circles in (a)-(e) highlight non-winter months, and SU, MI, HU, ER, and $\mathrm{ON}$ in (f) stand for lakes Superior, Michigan, Huron, Erie, and Ontario, respectively.

Time series of monthly averages in the VIIRS-derived water turbidity for the five individual lakes in the Great Lakes were constructed (Figure 6). All valid pixels over waters in the individual lakes were spatially and temporally averaged to produce the corresponding monthly mean value for each lake. The time series results provide apparent interannual variability in the VIIRS-derived water turbidity in the Great Lakes. Significantly high peaks of water turbidity appeared in May and October 2014 for Lake Superior, October 2014 for Lake Michigan, and September 2015 for Lake Ontario. In Lake Erie, 
the highest turbidity values generally appeared in the winter (December to February), and the lowest values are in the summer (June to August). On the other hand, relatively high turbidity peaks were present in October 2015 and March 2017. The apparent higher water turbidity values may be related to local physical and/or biological events such as high winds, river discharge, or phytoplankton blooms.

\subsection{VIIRS-Derived Climatology Water Turbidity}

A climatology (from 2012 to 2018) map of the VIIRS-derived water turbidity for the Great Lakes is provided in Figure 7. General spatial distributions from the VIIRS-derived water turbidity image are similar to the climatology monthly images shown in Figure 4. The water turbidity is the highest in Lake Erie, with mean and median values of 2.87 and 2.04 NTU over the entire Lake Erie, respectively, while the relatively lower values appeared in Lake Michigan (mean and median values of $\sim 0.48$ and $\sim 0.26 \mathrm{NTU}$ ) and Lake Huron (mean and median values of $\sim 0.55$ and $\sim 0.25 \mathrm{NTU}$ ). For Lake Superior, mean and median values of water turbidity are 0.51 and $0.32 \mathrm{NTU}$, respectively, while they are 0.50 and 0.41 NTU for Lake Ontario, respectively. Although water turbidity values are generally low in most areas in lakes Superior, Michigan, and Huron (around 0.15-0.25 NTU), significantly high values in water turbidity are shown in some coastal bays of those lakes with values > 10 NTU (e.g., Thunder Bay, Green Bay, and Saginaw Bay). Overall, Lake Erie has the highest water turbidity value. In addition, water turbidity values are apparently much higher in the western area of Lake Erie than that in the eastern area.
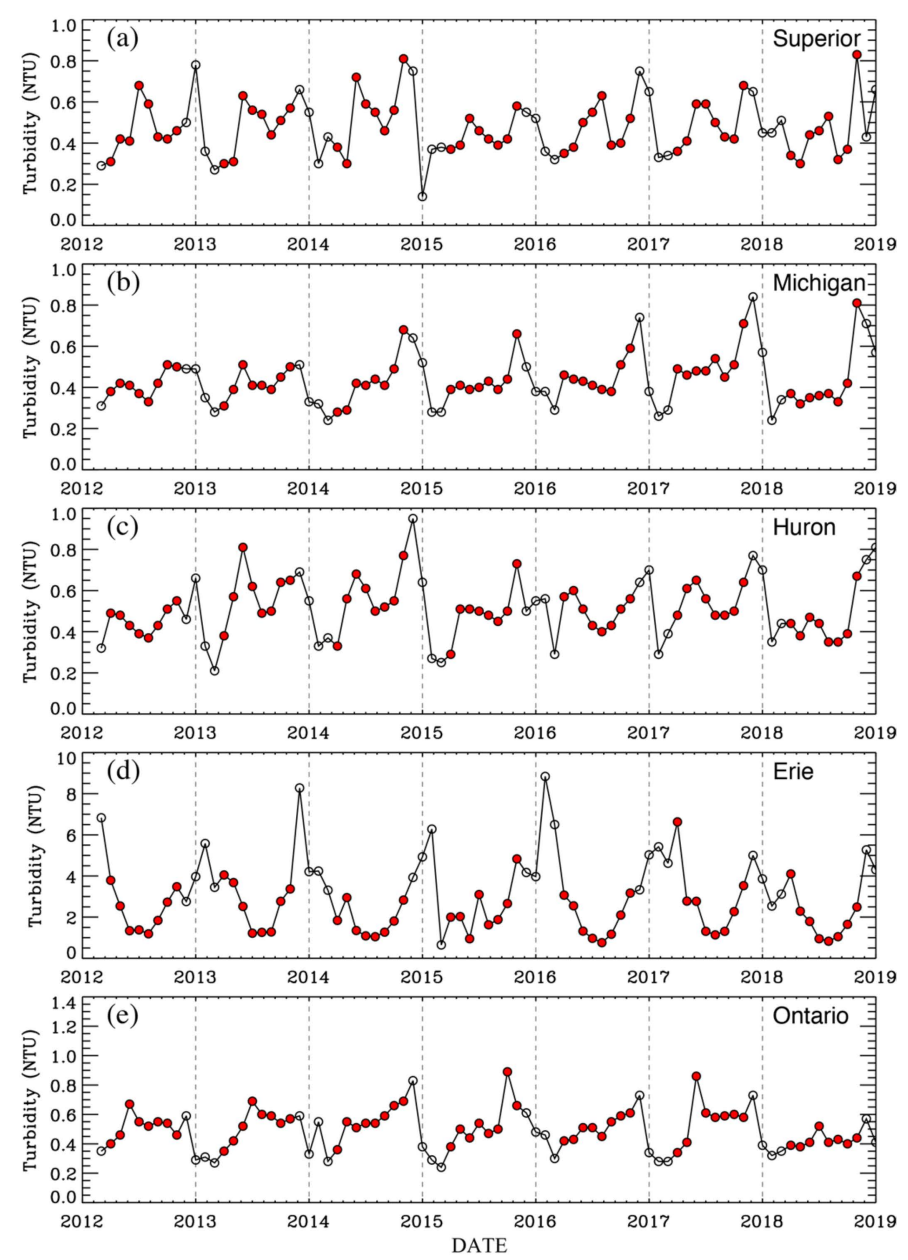

Figure 6. Time series of the VIIRS-SNPP-derived mean monthly water turbidity in the Great Lakes for (a) Lake Superior, (b) Lake Michigan, (c) Lake Huron, (d) Lake Erie, and (e) Lake Ontario. 


\section{Discussions}

There are a few studies of the seasonal distribution of water turbidity in the entirety of the Great Lakes. A recent study investigated the long-term water clarity changes in the Great Lakes using the multi-sensors satellite ocean color data [12]. In the study, the water clarity changes are based on the satellite-derived Secchi depth for the Great Lakes, which could be related to the water turbidity. The study separated the Great Lakes into offshore and nearshore areas for the seasonal distributions of the Secchi depth, while our results are based on the mean values of the entire lake. However, the general seasonal distribution of the Secchi depth seems to be inversely correlated to the water turbidity from our results. For example, the seasonal pattern of the MODIS-derived Secchi depth in Lake Erie in Binding et al. [12] is evidently well correlated inversely to that of the VIIRS-derived water turbidity in Figure 5d. It has been shown that large-scale whiting events in August or September have influenced water clarity in lakes Michigan and Ontario [44,45]. It seems that the significantly high turbidity in September 2015 in Lake Ontario (Figure 6e) was related to the whiting event. Indeed, the water turbidity in Lake Erie had strong influences from suspended sediments and cyanobacterial blooms $[17,18,46,47]$.

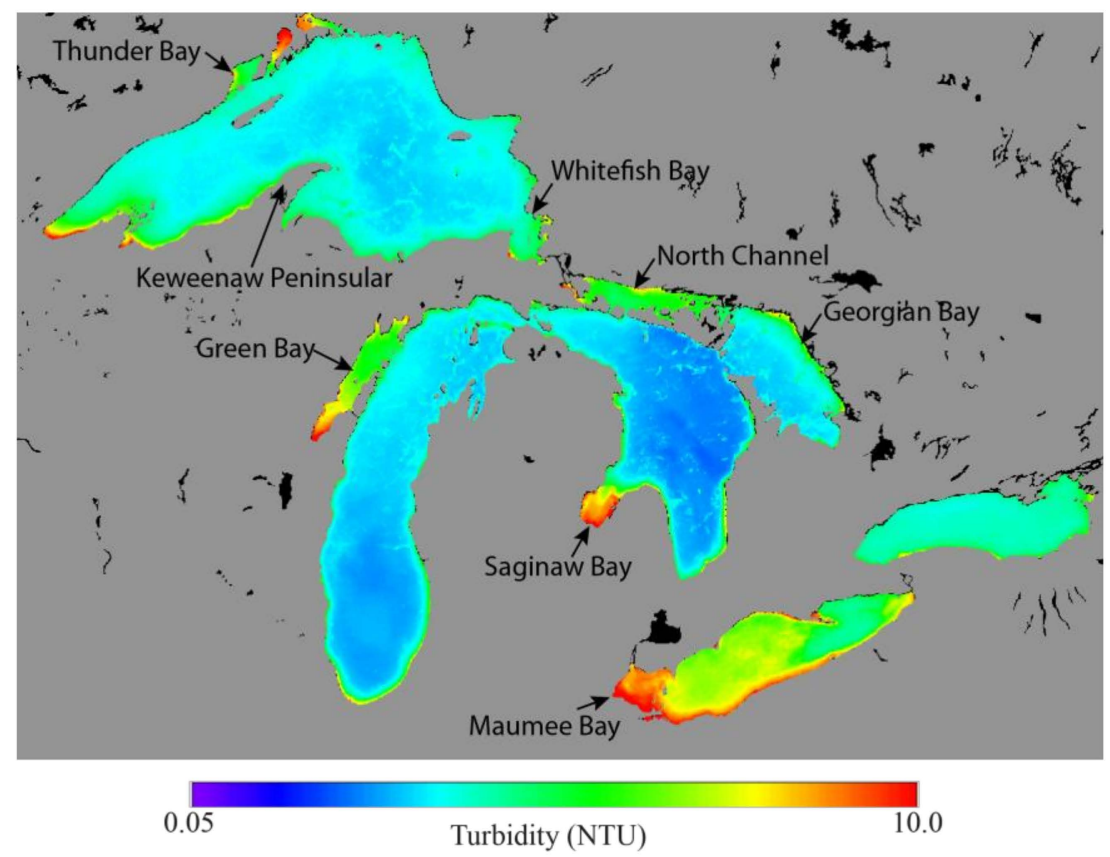

Figure 7. VIIRS-SNPP-measured climatology (2012-2018) water turbidity in the Great Lakes.

The highest water turbidity in Lake Erie can be related to the fact that it is the shallowest bathymetry lake in the Great Lakes. Thus, suspended sediments play a more major role in Lake Erie than any of the other lakes [46]. In addition, massive cyanobacteria harmful algal blooms have occurred annually in Lake Erie since the mid 1990s [17,18], which can have significant influences on water turbidity in the summer. The relatively high turbidity value in October 2015 in Lake Erie was likely caused by a large amount of sediment due to extensive wind mixing [48]. It has been reported that there were significant long-term trends in water quality properties in the Great Lakes $[12,16,22,24]$. This study is based on VIIRS ocean color data, which are available only from 2012 (about seven years). Thus, it is not possible to investigate long-term trends in water turbidity using the VIIRS data. Instead, in situ water turbidity measurements are available for all years since 1983 in the Great Lakes. Water turbidity data in the individual lakes were analyzed for four time periods, i.e., 1983-1990, 1991-2000, 2001-2010, and 2011-2017, to compare decadal changes in water turbidity with results from the previous studies in the Great Lakes (Table 1). While no consistent trend in water turbidity is indicated in Lake Superior and Lake Ontario, apparent decreasing trends in water turbidity appeared in Lake Michigan and 
Lake Huron. The decreasing trend of water turbidity in lakes Michigan and Huron is consistent with results from other studies, with an increasing trend in Secchi depth and transparency [12,22] and a decreasing trend in the water diffuse attenuation coefficient $[16,24]$. The decreased water turbidity could be caused by a reduced phytoplankton biomass and primary production [21,49]. In Lake Erie, on the other hand, water turbidity has apparently increased since the 2000s, particularly in spring months. It has been found that significant decreases in water clarity in the western basin of Lake Erie appeared in spring [50], which seems to be driven by large sediment loads into the western basin and the resuspension of inorganic particulates. However, it is noted that total number of water turbidity measurements varied depending on lakes and time periods. Thus, the mean turbidity values for each lake and each period might not be represented evenly.

Table 1. Mean (AVG), standard deviation (STD), and data number (No) of in situ water turbidity in the individual lake of the Great Lakes for the four time periods, i.e., 1983-1990, 1991-2000, 2001-2010, and 2011-2017, for all months, spring months, and summer months (total data number is 4708).

\begin{tabular}{|c|c|c|c|c|c|c|c|}
\hline \multirow[b]{2}{*}{ Lake } & \multirow[b]{2}{*}{ Period } & \multicolumn{2}{|c|}{ ALL SEASON } & \multicolumn{2}{|l|}{ SPRING } & \multicolumn{2}{|c|}{ SUMMER } \\
\hline & & $\begin{array}{c}\text { Turbidity } \\
\text { (NTU) } \\
(\mathrm{AVG} \pm \mathrm{STD})\end{array}$ & No & $\begin{array}{c}\text { Turbidity } \\
\text { (NTU) } \\
(A V G \pm \text { STD) }\end{array}$ & No & $\begin{array}{c}\text { Turbidity } \\
\text { (NTU) } \\
\text { (AVG } \pm \text { STD) }\end{array}$ & No \\
\hline \multirow{4}{*}{ Superior } & 1983-1990 & - & - & - & - & - & - \\
\hline & 1991-2000 & $0.15 \pm 0.12$ & 237 & $0.15 \pm 0.15$ & 129 & $0.15 \pm 0.08$ & 108 \\
\hline & 2001-2010 & $0.26 \pm 0.17$ & 249 & $0.29 \pm 0.20$ & 132 & $0.24 \pm 0.11$ & 117 \\
\hline & $2011-2017$ & $0.24 \pm 0.10$ & 203 & $0.24 \pm 0.12$ & 91 & $0.22 \pm 0.09$ & 112 \\
\hline \multirow{4}{*}{ Michigan } & 1983-1990 & $0.41 \pm 0.21$ & 447 & $0.41 \pm 0.22$ & 184 & $0.41 \pm 0.21$ & 263 \\
\hline & $1991-2000$ & $0.48 \pm 0.40$ & 323 & $0.38 \pm 0.21$ & 143 & $0.56 \pm 0.49$ & 180 \\
\hline & $2001-2010$ & $0.35 \pm 0.17$ & 138 & $0.37 \pm 0.16$ & 60 & $0.33 \pm 0.18$ & 78 \\
\hline & $2011-2017$ & $0.23 \pm 0.11$ & 130 & $0.23 \pm 0.15$ & 63 & $0.22 \pm 0.07$ & 67 \\
\hline \multirow{4}{*}{ Huron } & 1983-1990 & $0.33 \pm 0.17$ & 389 & $0.44 \pm 0.17$ & 154 & $0.26 \pm 0.12$ & 235 \\
\hline & $1991-2000$ & $0.31 \pm 0.17$ & 191 & $0.40 \pm 0.16$ & 115 & $0.18 \pm 0.07$ & 76 \\
\hline & 2001-2010 & $0.27 \pm 0.13$ & 174 & $0.32 \pm 0.14$ & 90 & $0.22 \pm 0.08$ & 84 \\
\hline & 2011-2017 & $0.21 \pm 0.15$ & 135 & $0.23 \pm 0.18$ & 59 & $0.20 \pm 0.11$ & 76 \\
\hline \multirow{4}{*}{ Erie } & 1983-1990 & $2.65 \pm 4.28$ & 668 & $3.51 \pm 5.42$ & 281 & $2.03 \pm 3.07$ & 387 \\
\hline & $1991-2000$ & $3.28 \pm 5.44$ & 395 & $4.44 \pm 6.36$ & 259 & $1.08 \pm 1.29$ & 136 \\
\hline & 2001-2010 & $4.38 \pm 7.88$ & 303 & $6.25 \pm 9.60$ & 172 & $1.91 \pm 3.50$ & 131 \\
\hline & 2011-2017 & $3.99 \pm 6.94$ & 221 & $6.05 \pm 9.10$ & 105 & $2.13 \pm 3.13$ & 116 \\
\hline \multirow{4}{*}{ Ontario } & 1983-1990 & $0.99 \pm 0.61$ & 155 & $0.40 \pm 0.23$ & 63 & $1.38 \pm 0.44$ & 92 \\
\hline & $1991-2000$ & $0.35 \pm 0.22$ & 143 & $0.26 \pm 0.14$ & 79 & $0.47 \pm 0.23$ & 64 \\
\hline & $2001-2010$ & $0.44 \pm 0.37$ & 118 & $0.29 \pm 0.18$ & 59 & $0.59 \pm 0.44$ & 59 \\
\hline & 2011-2017 & $0.56 \pm 0.44$ & 89 & $0.26 \pm 0.13$ & 38 & $0.79 \pm 0.45$ & 51 \\
\hline
\end{tabular}

It is noted that daily mean valid pixels in the VIIRS-derived ocean color products are considerably small during the winter season in the Great Lakes (e.g., $<\sim 10 \%$ in November, $<\sim 4 \%$ in December and January, and $<\sim 8 \%$ in February) due to the severe weather conditions such as clouds, snow, and ice covers (Figure 8). Thus, the monthly mean water turbidity values from VIIRS composite images during the months of November to February in the Great Lakes in Figures 5 and 6 may not be representative for all of the lakes. In fact, the water clarity study by Binding et al. [12] also excluded the satellite data from November to February for the long-term changes in the Great Lakes. 


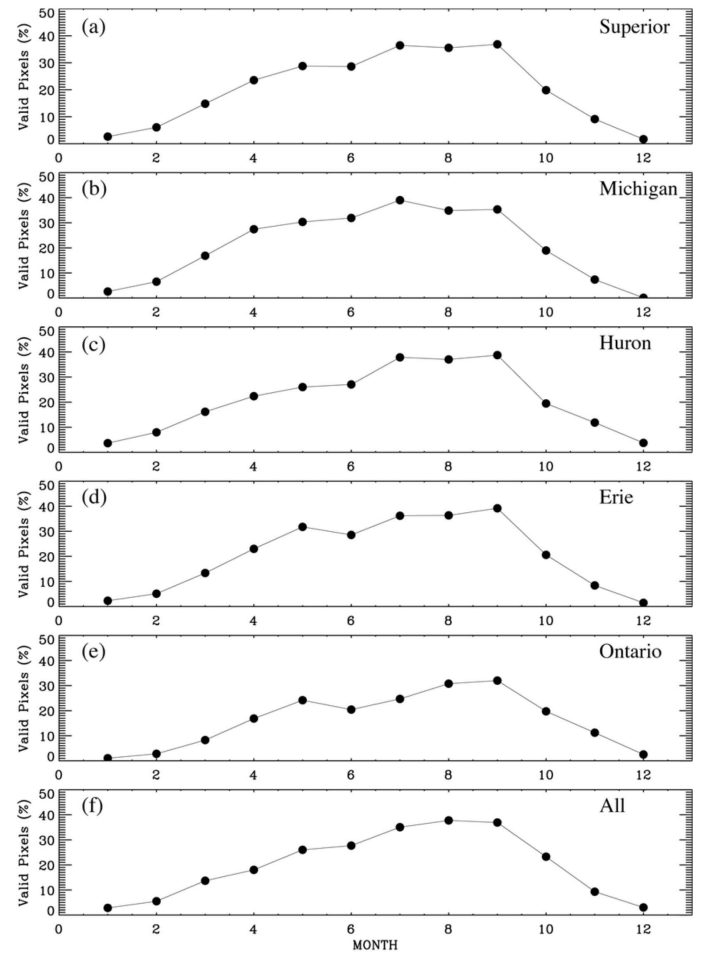

Figure 8. Mean valid pixels of daily VIIRS-SNPP-derived ocean color data in each month for (a) Lake Superior, (b) Lake Michigan, (c) Lake Huron, (d) Lake Erie, (e) Lake Ontario, and (f) all lakes.

Another concern is the spatial differences of the VIIRS-derived water turbidity in each lake. The monthly mean of the water turbidity could be influenced by relatively high turbidity in the shallow bays, such as Green Bay and Saginaw Bay, or regional massive blooms such as the cyanobacteria harmful algal blooms in Lake Erie. It is particularly noted that the main objective of this study is to derive a regional water turbidity algorithm from VIIRS ocean color measurements in the Great Lakes and to examine the general spatial and temporal distributions of the VIIRS-derived water turbidity maps using the proposed algorithm. Some more specific investigations of the quantitative patterns in the water turbidity for separated areas in the Great Lakes, e.g., nearshore or offshore, will need to be carried out in a future study.

\section{Conclusions}

A regional water turbidity algorithm for the satellite ocean color applications has been developed for the Great Lakes using a robust relationship between the in situ water turbidity measurements and the water diffuse attenuation coefficient at the wavelength of $490 \mathrm{~nm}, K_{d}(490)$, from the VIIRS ocean color observations. The proposed algorithm for satellite ocean color applications can reasonably measure water turbidity in the Great Lakes. Results show that VIIRS-derived water turbidity data using the proposed regional algorithm are well correlated to the in situ water turbidity measurements in the Great Lakes. VIIRS-derived water turbidity images provide synoptic maps of water turbidity in the Great Lakes to study spatial and temporal variability of water turbidity in the entirety of the Great Lakes. Results show that higher water turbidity values appeared in the nearshore waters including Thunder Bay, Green Bay, and Saginaw Bay. The highest water turbidity in Lake Erie seems to be strongly related to suspended sediments due to the shallow bathymetry and frequent massive cyanobacterial blooms in the lake. The relatively higher water turbidity values in Lake Ontario, compared with those in lakes Superior, Michigan, and Huron, may be related to phytoplankton blooms and whiting events. In addition, time series of monthly averages of the VIIRS-derived water turbidity data provide a strong interannual variability in the Great Lakes. This study has demonstrated that the proposed regional water turbidity algorithm can be effectively used to monitor, characterize, and quantify water 
turbidity in the Great Lakes using VIIRS ocean color data. Furthermore, to fully assess long-term decadal water turbidity properties and biogeochemical processes in the Great Lakes, as well as its interaction with human activities and climate variability, it will be useful to generate datasets using satellite observations from the past (historical) (e.g., CZCS, SeaWiFS), present (MODIS, VIIRS, OLCI, SGLI, etc.), and future satellite ocean color data with refined water turbidity algorithms.

Author Contributions: S.S. carried out the main research work for developing the algorithm, obtaining the results, and analyzing the data. M.W. suggested the topic and contributed to the algorithm development and evaluation.

Funding: This research was supported by the Joint Polar Satellite System (JPSS) funding and NOAA Product Development, Readiness, and Application (PDRA)/Ocean Remote Sensing (ORS) Program funding.

Acknowledgments: In situ water turbidity data for the Great Lakes were obtained from the EPA's Great Lake Environmental Database System (GLENDA). The views, opinions, and findings contained in this paper are those of the authors and should not be construed as an official NOAA or U.S. Government position, policy, or decision.

Conflicts of Interest: The authors declare no conflict of interest.

\section{References}

1. Kieser, M.S.; Canale, R.P.; Auer, M.T. Identification of Critical Nutrient Levels through Field Verification of Models for Phosphorus and Phytoplankton Growth. Can. J. Fish. Aquat. Sci. 1986, 43, 379-388.

2. Environment Canada. Threats to Sources of Drinking Water and Aquatic Ecosystem Health in Canada; NWRI Scientific Assessment Report Ser. No. 1; National Water Research Institute: Burlington, ON, Canada, 2001.

3. EPA. The Great Lakes: An Environmental Atlas and Resource Book, 3rd ed.; Government of Canada: Toronto, ON, Canada; United States Environmental Protection Agency: Chicago, IL, USA, 1995.

4. Millard, E.S.; Sager, P.E. Comparison of Phosphorus, Light Climate, and Photosynthesis between Two Culturally Eutrophied Bays: Green Bay, Lake Michigan, and the Bay of Quinte, Lake Ontario. Can. J. Fish. Aquat. Sci. 1994, 51, 2579-2590. [CrossRef]

5. Gordon, H.R.; Clark, D.K.; Mueller, J.L.; Hovis, W.A. Phytoplankton Pigments from the Nimbus-7 Coastal Zone Color Scanner: Comparisons with Surface Measurements. Science 1980, 210, 63-66. [CrossRef] [PubMed]

6. Hovis, W.; Clark, D.; Anderson, F.; Austin, R.; Wilson, W.; Baker, E.; Ball, D.; Gordon, H.; Mueller, J.; Sayed, S.; et al. Nimbus 7 Coastal Zone Color Scanner: System description and Intial imagery. Science 1980, 210, 60-63. [CrossRef] [PubMed]

7. McClain, C.R.; Feldman, G.C.; Hooker, S.B. An overview of the SeaWiFS project and strategies for producing a climate research quality global ocean bio-optical time series. Deep. Sea Res. Part II Top. Stud. Oceanogr. 2004, 51, 5-42. [CrossRef]

8. Salomonson, V.; Barnes, W.; Maymon, P.; Montgomery, H.; Ostrow, H. MODIS: Advanced facility instrument for studies of the Earth as a system. IEEE Trans. Geosci. Remote. Sens. 1989, 27, 145-153. [CrossRef]

9. Goldberg, M.D.; Kilcoyne, H.; Cikanek, H.; Mehta, A. Joint Polar Satellite System: The United States next generation civilian polar-orbiting environmental satellite system. J. Geophys. Res. Atmos. 2013, 118, 13463-13475. [CrossRef]

10. Gons, H.J.; Auer, M.T.; Effler, S.W. MERIS satellite chlorophyll mapping of oligotrophic and eutrophic waters in the Laurentian Great Lakes. Remote. Sens. Environ. 2008, 112, 4098-4106. [CrossRef]

11. Binding, C.; Jerome, J.; Bukata, R.; Booty, W. Suspended particulate matter in Lake Erie derived from MODIS aquatic colour imager. Int. J. Remote Sens. 2010, 31, 5239-5255. [CrossRef]

12. Binding, C.E.; Greenberg, T.A.; Watson, S.B.; Rastin, S.; Gould, J. Long term water clarity changes in North America's Great Lakes from multi-sensor satellite observations. Limnol. Oceanogr. 2015, 60, 1976-1995. [CrossRef]

13. Lesht, B.; Barbiero, R.; Warren, G. A band-ratio algorithm for retrieving open-lake chlorophyll values from satelite observations of the Great Lakes. J. Great Lakes Res. 2013, 39, 138-152. [CrossRef]

14. Pozdnyakov, D.; Shuchman, R.; Korosov, A.; Hatt, C. Operational algorithm for the retrieval of water quality in the Great Lakes. Remote. Sens. Environ. 2005, 97, 352-370. [CrossRef] 
15. Shuchman, R.A.; Leshkevich, G.; Sayers, M.J.; Johengen, T.H.; Brooks, C.N.; Pozdnyakov, D. An algorithm to retrieve chlorophyll, dissolved organic carbon, and suspended minerals from Great Lakes satellite data. J. Great Lakes Res. 2013, 39, 14-33. [CrossRef]

16. Yousef, F.; Shuchman, R.; Sayers, M.; Fahnenstiel, G.; Henareh, A. Water clarity of the Upper Great Lakes: Tracking changes between 1998-2012. J. Great Lakes Res. 2017, 43, 239-247. [CrossRef]

17. Moore, T.; Mouw, C.; Sullivan, J.; Twardowski, M.; Burtner, A.; Ciochetto, A.; McFarland, M.; Nayak, A.; Paladino, D.; Stockley, N.; et al. Bio-optical properties of cyanobacteria blooms in western Lake Erie. Front. Mar. Sci. 2017, 4, 300. [CrossRef]

18. Stumpf, R.P.; Wynne, T.T.; Baker, D.B.; Fahnenstiel, G.L. Interannual Variability of Cyanobacterial Blooms in Lake Erie. PLoS ONE 2012, 7, e42444. [CrossRef] [PubMed]

19. Wynne, T.T.; Tomlinson, M.C.; Stumpf, R.P.; Dyble, J. Characterizing a cyanobacterial bloom in Western Lake Erie using satellite imagery and meteorological data. Limnol. Oceanogr. 2010, 55, 2025-2036. [CrossRef]

20. Son, S.; Wang, M. Ice Detection for Satellite Ocean Color Data Processing in the Great Lakes. IEEE Trans. Geosci. Remote. Sens. 2017, 55, 6793-6804. [CrossRef]

21. Fahnenstiel, G.; Pothoven, S.; Vanderploeg, H.; Klarer, D.; Nalepa, T.; Scavia, D. Recent changes in primary production and phytoplankton in the offshore region of southeastern Lake Michigan. J. Great Lakes Res. 2010, 36, 20-29. [CrossRef]

22. Kerfoot, W.C.; Yousef, F.; Green, S.A.; Budd, J.W.; Schwab, D.J.; Vanderploeg, H.A. Approaching storm: Disappearing winter bloom in Lake Michigan. J. Great Lakes Res. 2010, 36, 30-41. [CrossRef]

23. Wang, J.; Bai, X.; Hu, H.; Clites, A.; Colton, M.; Lofgren, B. Temporal and spatial variability of Great Lakes ice cover, 1973-2010. J. Clim. 2011, 25, 1318-1329. [CrossRef]

24. Yousef, F.; Kerfoot, W.C.; Shuchman, R.; Fahnenstiel, G. Bio-optical properties and primary production of Lake Michigan: Insights from 13-years of SeaWiFS imagery. J. Great Lakes Res. 2014, 40, 317-324. [CrossRef]

25. Zolfaghari, K.; Duguay, C.R. Estimation of Water Quality Parameters in Lake Erie from MERIS Using Linear Mixed Effect Models. Remote. Sens. 2016, 8, 473. [CrossRef]

26. Lee, Z.-P.; Darecki, M.; Carder, K.L.; Davis, C.O.; Stramski, D.; Rhea, W.J. Diffuse attenuation coefficient of downwelling irradiance: An evaluation of remote sensing methods. J. Geophys. Res. Space Phys. 2005, 110, C02017. [CrossRef]

27. Wang, M.; Son, S.; Harding, L.W. Retrieval of diffuse attenuation coefficient in the Chesapeake Bay and turbid ocean regions for satellite ocean color applications. J. Geophys. Res. Space Phys. 2009, 114, C10011. [CrossRef]

28. Wang, M.; Liu, X.; Tan, L.; Jiang, L.; Son, S.; Shi, W.; Rausch, K.; Voss, K. Impacts of VIIRS SDR performance on ocean color products. J. Geophys. Res. Atmos. 2013, 118, 10347-10360. [CrossRef]

29. Wang, M.; Jiang, L.; Liu, X.; Son, S.; Sun, J.; Shi, W.; Tan, L.; Mikelsons, K.; Wang, X.; Lance, V. VIIRS ocean color products: A progress update. In Proceedings of the 2016 IEEE International Geoscience and Remote Sensing Symposium (IGARSS), Beijing, China, 10-15 July 2016; pp. 5848-5851.

30. Sun, J.; Wang, M. Radiometric calibration of the VIIRS reflective solar bands with robust characterizations and hybrid calibration coefficients. Appl. Opt. 2015, 54, 9331-9342. [CrossRef]

31. Sun, J.; Wang, M. VIIRS Reflective Solar Bands Calibration Progress and Its Impact on Ocean Color Products. Remote. Sens. 2016, 8, 194. [CrossRef]

32. Wang, M. A Sensitivity Study of the SeaWiFS Atmospheric Correction Algorithm Effects of Spectral Band Variations. Remote. Sens. Environ. 1999, 67, 348-359. [CrossRef]

33. Wang, M.; Franz, B. Comparing the ocean color measurements between MOS and SeaWiFS: A vicarious intercalibration approach for MOS. IEEE Trans. Geosci. Remote. Sens. 2000, 38, 184-197. [CrossRef]

34. Wang, M.; Isaacman, A.; Franz, B.A.; McClain, C.R. Ocean-color optical property data derived from the Japanese Ocean Color and Temperature Scanner and the French Polarization and Directionality of the Earth's Reflectances: A comparison study. Appl. Opt. 2002, 41, 974-990. [CrossRef] [PubMed]

35. Gordon, H.R.; Wang, M. Retrieval of water-leaving radiance and aerosol optical thickness over the oceans with SeaWiFS: A preliminary algorithm. Appl. Opt. 1994, 33, 443-452. [CrossRef] [PubMed]

36. Jiang, L.; Wang, M. Improved near-infrared ocean reflectance correction algorithm for satellite ocean color data processing. Opt. Express 2014, 22, 21657-21678. [CrossRef] [PubMed]

37. Wang, M. Remote sensing of the ocean contributions from ultraviolet to near-infrared using the shortwave infrared bands: Simulations. Appl. Opt. 2007, 46, 1535-1547. [CrossRef] [PubMed] 
38. Wang, M.; Shi, W. Estimation of ocean contribution at the MODIS near-infrared wavelengths along the east coast of the U.S.: Two case studies. Geophys. Res. Lett. 2005, 32, L13606. [CrossRef]

39. Wang, M.; Shi, W. The NIR-SWIR combined atmospheric correction approach for MODIS ocean color data processing. Opt. Express 2007, 15, 15722-15733. [CrossRef]

40. Wang, M.; Shi, W. Sensor Noise Effects of the SWIR Bands on MODIS-Derived Ocean Color Products. IEEE Trans. Geosci. Remote. Sens. 2012, 50, 3280-3292. [CrossRef]

41. Wang, M.; Son, S.; Shi, W. Evaluation of MODIS SWIR and NIR-SWIR atmospheric correction algorithms using SeaBASS data. Remote. Sens. Environ. 2009, 113, 635-644. [CrossRef]

42. Wang, M.; Nim, C.J.; Son, S.; Shi, W. Characterization of turbidity in Florida's Lake Okeechobee and Caloosahatchee and St. Lucie estuaries using MODIS-Aqua measurements. Water Res. 2012, 46, 5410-5422. [CrossRef]

43. Shi, W.; Wang, M. Ocean reflectance spectra at the red, near-infrared, and shortwave infrared from highly turbid waters: A study in the Bohai Sea, Yellow Sea, and East China Sea. Limnol. Oceanogr. 2014, 59, 427-444. [CrossRef]

44. Peng, F.; Effler, S.W. Characterizations of the light-scattering attributes of mineral particles in Lake Ontario and the effects of whiting. J. Great Lakes Res. 2011, 37, 672-682. [CrossRef]

45. Strong, A.; Eadie, B. Satellite observations of calcium carbonate precipitations in the Great Lakes. Limnol. Oceanogr. 1978, 23, 877-887. [CrossRef]

46. Mortimer, C. Fifty Years of Physical Investigations and Related Limnological Studies on Lake Erie, 1928-1977. J. Great Lakes Res. 1987, 13, 407-435. [CrossRef]

47. Steffen, M.M.; Belisle, B.S.; Watson, S.B.; Boyer, G.L.; Wilhelm, S.W. Status, causes and controls of cyanobacterial blooms in Lake Erie. J. Great Lakes Res. 2014, 40, 215-225. [CrossRef]

48. National Centers for Coastal Ocean Science and Great Lakes Environmental Research Laboratory, "Experimental Lake Erie Harmful Algal Bloom Bulletin," Harmful Algal Blooms in Lake Erie, Bulletin 25, 8 October 2015. Available online: https://glerl.noaa.gov/res/HABs_and_Hypoxia/lakeErieHABArchive/ bulletin_2015-025.pdf (accessed on 18 June 2019).

49. Barbiero, R.P.; Lesht, B.M.; Warren, G.J. Evidence for bottom-up control of recent shifts in the pelagic food web of Lake Huron. J. Great Lakes Res. 2011, 37, 78-85. [CrossRef]

50. Barbiero, R.P.; Tuchman, M.L. Long-term Dreissenid Impacts on Water Clarity in Lake Erie. J. Great Lakes Res. 2004, 30, 557-565. [CrossRef] 